\title{
Reasons for the Wide Spread of the Protosyllable -*kam- (and Its Phonetic Variants -*kham-, -*cham-) in the Modern Place-Names (Multidisciplinary Approach)
}

\author{
Elena A. Mironova, Konstantin N. Shkvarya \\ Department of Linguistics and Cross-Cultural Communication, Rostov State University of Economics, Rostov-on-Don, Russia \\ Email: almir@donpac.ru
}

How to cite this paper: Mironova, E. A., \& Shkvarya, K. N. (2018). Reasons for the Wide Spread of the Protosyllable -*kam(and Its Phonetic Variants -*kham-, -* cham-) in the Modern Place-Names (Multidisciplinary Approach). Advances in Anthropology, 8, 273-288.

https://doi.org/10.4236/aa.2018.84011

Received: August 13, 2018

Accepted: October 12, 2018

Published: October 15, 2018

Copyright $\odot 2018$ by authors and Scientific Research Publishing Inc. This work is licensed under the Creative Commons Attribution International License (CC BY 4.0).

http://creativecommons.org/licenses/by/4.0/

\begin{abstract}
This article presents a new approach in the field of protolanguage study on the basis of the hypothesis (Mironova, 2008) about protosyllables of protolanguage preserved in the modern place names. The protosyllable - ${ }^{\star} \mathrm{kam}-\mathrm{ex}-$ ists since ancient times in hydronyms and oronyms, and shows the presence of common ancient meaning in their phonetic arrangement. The research reveals this common meaning inserted in the protosyllable -*kam-, which reflects the attitude of migrated tribes to the sacred mountains and mountain ranges on the one hand and water sources on the other. The traces of these migrated tribes can be found according to the up-to-date investigations in the field of archaeology (stone artifacts in the shape of a bear and an elk), in the field of DNA-genealogy (the data about "Malta boy" Y-chromosome haplogroup R) and in the field of the Paleolithic religious cult study (common features of the united religious cult of the Great Goddess of the Paleolithic in Eurasia, including: heart-like and anthropomorphic images on the surfaces and on the corners of the stones, boulders and cliffs).
\end{abstract}

\section{Keywords}

Protolanguage, Protosyllables, Place Names, Ancient Migrations, DNA-Genealogy, Eurasian Paleolithic Cult, Great Goddess, Interdisciplinary Approach

\section{Introduction}

Interdisciplinary research brings the most surprising results in the modern science as it helps to analyze a problem by means of cross-checking, with different scientific methods and approaches based on technological advantages. For 
the last few years such approach delivered a real breakthrough in the field of reassessment of our knowledge of the past. In particular, the analysis of DNA-genealogy data on migrations of the Eurasian oldest ethnic groups (Klyosov, 2012; Klyosov \& Rozhanskii, 2012) as well as the analysis of data on spreading the Proto-Indo-European language in today's world toponyms (Mironova, 2008) could help in finding the language-ancestor.

\section{DNA-Genealogy Data Relevant to the Linguistic Study}

DNA-genealogy established few years ago by a state science award winner (USSR, 1984), Moscow State University and Harvard University professor Anatoly A. Klyosov is an effective means in search for the traces of ancient migrations on the territory of Eurasia. According to this data, we can suppose the common language that existed at that time and that could be spread and established across the explored territories.

The earliest bearer of the haplogroup R (ancestor of the haplogroups R1a and R1b) lived in Malta-the Siberian settlement, $85 \mathrm{~km}$ to the west of Irkutsk. The data about his decoded genome was published in September, 2013 in "Science". There the results of a new research fulfilled by the international group of geneticists under the leadership of Eske Willerslev were published. With a sample of a bone from the double Upper-Paleolithic burial on the settlement Malta in Irkutsk Region, it could be possible to sequence the genome of the 24,000-year-old Malta boy from central Siberia. This is the most ancient in science genome of a representative of a kind of Homo sapiens and it belongs to the haplogroup $\mathrm{R}$ (Yong, 2013).

Haplogroup $\mathrm{R}$ is the ancestral for the haplogroups R1b and R1a-the basic Caucasoid haplogroups, who inhabited Russian Plain and Europe. In 2012 professor Anatole A. Klyosov wrote that haplogroup R1b appeared in Southern Siberia from the haplogroup R1. The haplogroup R1 appeared from haplogroup R, also in Southern Siberia, 26 thousand years ago. The haplogroup R appeared from haplogroup P, the bearers of which came to Southern Siberia about 40 thousand years ago (Klyosov, 2012: p. 103): "The results of this study lend a support to the theory that haplogroup R1b arose in Central Asia, apparently in South Siberia or the neighboring regions, around 16,000 years before present. The preceding history of the haplogroup is directly related to the appearance of Europeoids (Caucasoids) 58,000 ybp, likely in the vast triangle that stretched from Western Europe through the Russian Plain to the east and to Levant to the south, as it was suggested in (Klyosov, 2011). A subsequent sequence of SNP mutations in Y chromosome, with the appearance of haplogroups NOP $\sim 48,000$ ybp and $\mathrm{P} \sim 38,000 \mathrm{ybp}$ in the course of their migration eastward to South Siberia, eventually gave rise to haplogroup $\mathrm{R} \sim 30,000 \mathrm{ybp}$ and $\mathrm{R} 1 \sim 26,000 \mathrm{ybp}$, and then to haplogroup R1a/R1a1 20,000 ybp (the timeframe between the appearance of $\mathrm{R} 1 \mathrm{a}$ and R1a1 is uncertain) and R1b 16,000 ybp" (Klyosov, 2012: p. 103).

Further migrations of two branches of ancestral haplogroup R1 (the descen- 
dent from haplogroup R) - the haplogroups R1a and R1b were than traced in the research by Anatoly A. Klyosov and Igor L. Rozhanskii: "It should be mentioned here, that two brother subclades, R1a and R1b, have been migrating from Central Asia westward by two quite different routes. While R1a were moving along the southern route from the Altay region across the Himalayas, Hindustan, the Iranian plateau, Anatolia and the balance of Asia Minor to the Balkans (Klyosov \& Rozhanskii, 2012), R1b were moving along the northern route, from the same region across South Urals, Middle Asia, North Kazakhstan, Middle Volga, the Caucasus, and then split between the southward and west-ward directions" (Klyosov, 2012: p. 92).

\section{Archaeological Data Revealing the Common Eurasian Cult since the Paleolithic}

Archeological findings show the presence of identical artifacts found in different regions of Eurasia. This is not only the same ceramics, the same ornamental patterns, the same unique religious symbols on the pottery (Mironova, 2013), but also the stone artifacts, which were found recently on many archaeological sites. They are: double-sided (polyeiconic) zoomorphic pebbles, heart-like anthropomorphic images on the stones and mountains, corner anthropomorphic images (on the junction of two sides of a stone, a boulder or even a mountain). They all are spread across Eurasia, on different Paleolithic and Mesolithic settlements, from Brittany to the Far East (Mironova, 2014).

Here the double-sided polyeiconic zoomorphic pebbles formed under one religious canon are demonstrated. This canon could be identified via the following features: on the one side of a small flat stone (or specially selected flat pebble) the partial image of an animal is represented, namely-the partial head image of elk or deer. On the other side of the same flat stone (specially selected for this purpose) one can see a complete figure of polar bear (Osinoozerskaya settlement, Zamostie 2 site, Podti I site (Komi Republic) (Figures 1(a)-(d)).

The below shown artifacts include: 1) the stone sculpture from the settlement Michailovka-Klyuch (Osinoozerskaya archaeological culture of the Western Priamurie located on the left coast of the Upper and Middle Amur during Neolithic Age (final stage)-III-II thousand years BC.

The artifact was interpreted as a sculpture of a bear as soon as the removal of the facets from both sides of a stone (determined as an opal) has been done in order to underline the definite details of an exterior of a bear, namely, its muzzle and dewlap, underside, back and humpback. The archaeologists concluded that bi-facial processing turned the initial raw stock into miniature round sculpture. The absence of any traces of utilization also verify the non-utilitarian purpose of this artifact (Kovalenko, 2015: p. 44); 2) another looking alike object is from the settlement Zamostie and it is done on the initial pebble which was split in two halves (Figure 1(b)); 3) one more finding-a polyeiconic zoomorphic stone sculpture from the settlement Podty, republic Komi (was discovered by V.N. 


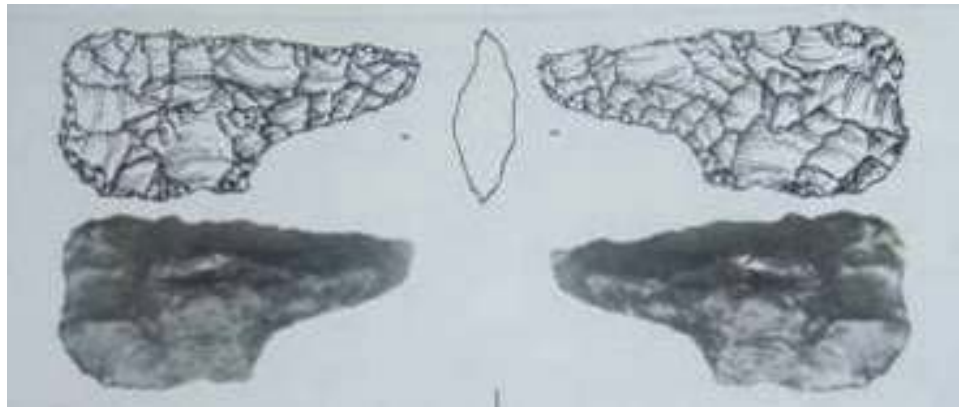

(a)

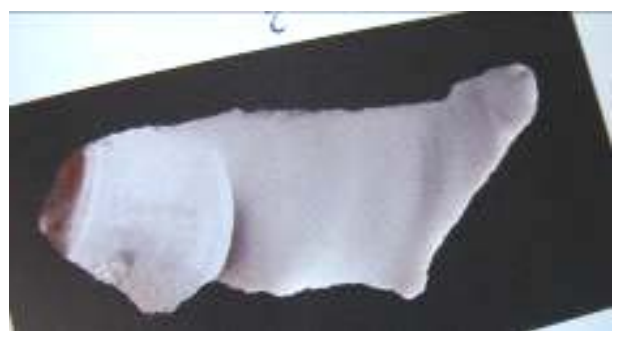

(c)

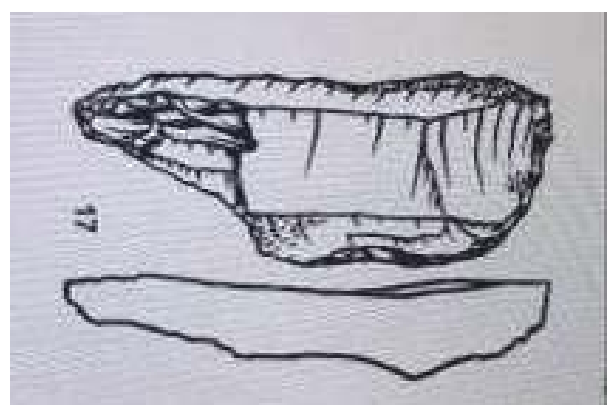

(b)

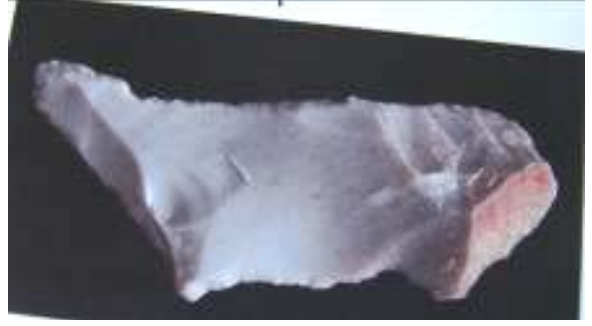

(d)

Figure 1. (a) Pebble-bear from Osinoozerskaya archaeological site, III-II thousand years BC (Kovalenko, 2015: p. 50); (b) Zamostie 2 settlement. Flint industry of the upper Mesolithic layer (Lozovskii, 2014: p. 275); (c) Stone sculpture, Podti I site (Komi Republic): the flat pebble with an image of a complete figure of a white polar bear with the raised head; (d) the opposite side of the same pebble-sculpture: a partial image of an elk head (this is a page from the book by Yu.B. Serikov "Outline on the prehistoric art of Ural", upon the correct placement of a page (Serikov, 2014).

Karmanov) also bears an image of an elk on one side-with the clearly depicted ear (Figure 1(d)), with sub-mandibular groove and long muzzle, which is formed by an ancient artist with a help of chopping, so that it turned to a partial image. On the other side there is an image of another animal-a polar bear with the raised head (Figure 1(c)), so that this image is a complete figure of a bear.

Recently found polyeiconic sculpture "bear-elk" was discovered near the water among coastal pebbles in Gelendzhik bay by one of the authors of this article (Mironova, 2017). The sculpture has the size: $4.3 \times 2.4 \mathrm{~cm}$, is made of the dark (almost black) hard stone (granite?) with the gray streaks and inclusions of mica, due to which the stone sparkles (which made it noticeable on the coast) (Figure 2(b)). It is worth mentioning that the other pebbles on the coast are light or even of white colour.

This pebble sculpture has (if not absolute identity) very close similarity with the artifact recently discovered and described in the report at the XXI-st Russian Archaeological Congress, 2-7 October 2017 (Barnaul-Belokuriha) by the archaeologists E.N. Bocharova and I.V. Zotkina. The artifact was found at the settlement Kazachka I, on the bank of the tribute of the river Yenisei-the river Kan (in the mouth of its right tribute-the Kazachka, on the high terrace (Bocharova \& Zotkina, 2017). The mentioned archaeological site is located in Kansk district of Krasnoyarsk Region. Geographically this is the north-western sub-region of Prisayanskii mountainous region and contact zone of the Kansk-Rybinsk basin and the Yenisei mountain range (Sergeev, 1962: p. 213). 


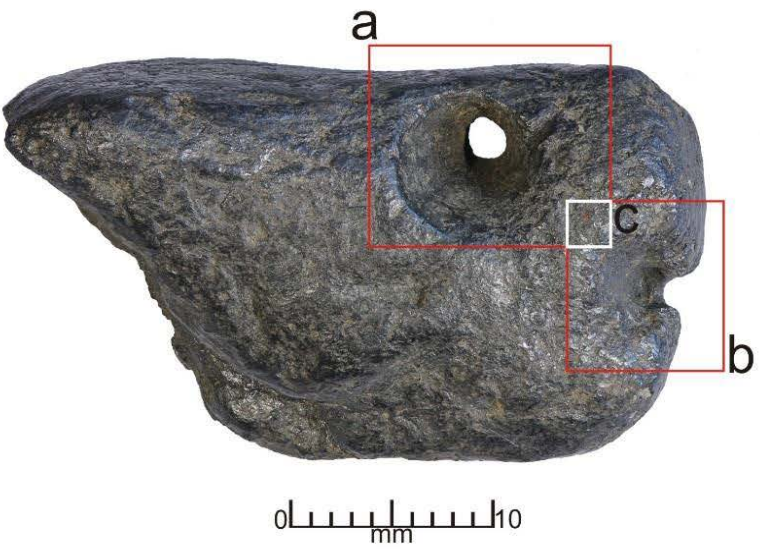

(a)

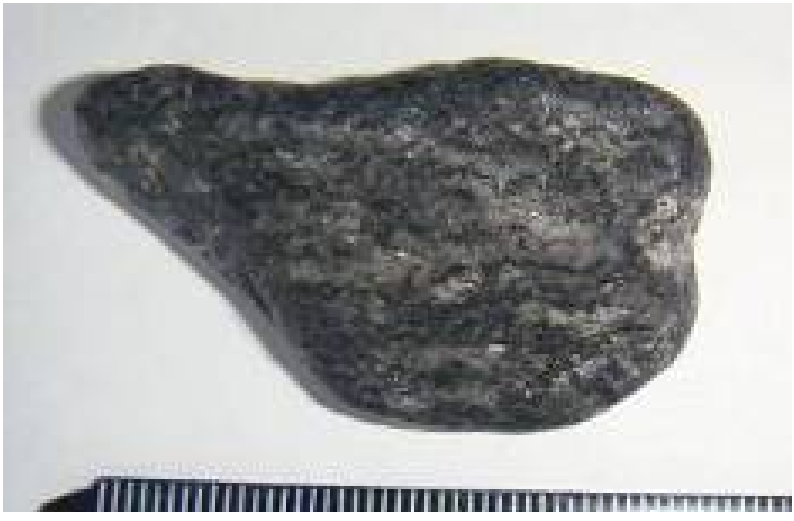

(b)

Figure 2. Two pebble-sculptures in comparison: (a) the artifact from the diggings on the settlement Kazachka-I, the catchment area of the Yenisei-the Kazachka river, 11,004 11,080 y.b.p. (Bocharova \& Zotkina, 2017); (b) the finding on the bank of the bay Gelendzhik (the finding and photo by Elena A. Mironova).

According to the authors of the finding, it is "a unique object" from the collection of XIX horizon of the settlement Kazachka-I. This is the artifact made of graphite with the drilled biconic holes. After the procedure of dating according to the paleomagnetic data, the artifact was referred to the interval between 11,004 - 11,080 y.b.p. (Generalov, 2001).

Description of this pebble sculpture according to E.N. Bocharova and L.V. Zotkina is as follows: "The artifact is a quadrangular subject, formed by polishing and has two holes: one is destroyed on the distal end of the subject, another one is perforated. This kind of subjects, which could be referred to the category of small plastic art were discovered neither on this settlement no on the nearest sites. The analysis of archaeological literature did not present any results in search for the analogues for the neighboring territories" (Bocharova \& Zotkina, 2017) (Figure 2(a)).

As soon as the authors did not find any parallels (artifacts from another sites in the neighboring territories) with their finding, they did not notice the visual similarity of it with a bear. 
As for the polyeiconic sculpture from Gelendzhik, found by Elena A. Mironova, the visual analysis revealed that the sculpture is done on the small pebble, split in halves, with the insignificant hole between them. One of the two sides (the surface with an image of elk muzzle) there is a transverse incision (on the surface with the figure of a bear with a narrow head-it is clear that it is a Polar bear).

To be accepted as an artifact, any processed stone has to meet the following conditions (Stolyar, 1985), namely: selection of the initial raw material which the nature could not do (initial raw material for the sculpture from Gelendzhik differs due to its texture-it sparkles, it attracts attention and it is of the standard dimension (standard for this type of artifacts found earlier); traces of influence (the pebble is split along and there is a transverse cut on one of its side); its finding, although, not in the archaeological layer but on the surface as an elevated material (which is acknowledged in the modern archaeology as valid), in the place of two elements meeting - water and soil-the place, which was considered as sacral by the ancient peoples. Consequently, it could be considered as a hand-made object-a zoomorphic polyeiconic sculpture.

\section{Religious Cult of Great Goddess, Common for Eurasia since Paleolithic}

Not only the pebble zoomorphic polyeiconic sculptures (bear-elk) manifest the traces of one and the same tribe representatives (and their descendents) migrations. Unity of culture could be traced from Brittany (France) to the Oceania with the help of another marker-the images of "Female Deity"- the Great Goddess (definition given by M. Gimbutas), recently found on the stone sculptures and other artifacts. Anthropomorphous heart-shaped images could be found on the pebbles as well as on the megaliths. Such anthropomorphic images, shaped in the form of a heart, with pit on the top in the center of a forehead, identified on the artifacts of the cave Yong-ok, in South Korea (Derevianko, 2011: pp. 2-29). Archeological sites were explored further and several culture layers were discovered: Chunnery and Khakhvadjery-all with multiple layers represented End of Stone Age final horizon (Figure 3). The age of these settlements is dated by 50 - 30 y.b.p. (Li, 2003). A.P. Derevianko states that, the tabulate industry (among the artifacts of this industry a heart-like pebble is found in the cave Yong-ok) came to the Korean peninsula from the south of Russian Far East and north-east of China: "Which events could have been behind this fact is difficult to identify. The new technology could have spread as a result of the contacts with the neighboring tribes and (or) due to their direct infiltration" (Derevianko, 2011: p. 22).

This is an anthropomorphic image en face as a heart with a cut in the center of a forehead and a narrowed or triangular low part of a face. This kind of images were already studied in the previous works (Mironova \& Popov, 2013), and they are the canonical depiction of the Great Goddess testifying the widespread of its cult on the territory of modern Korea. 
A.P. Okladnikov wrote about this kind of images as about specific local feature of the cliff art of the Far East region. This specific feature could be done on the joint of stone facets and allowed to use the natural relief of the stone (Okladnikov, 1971: pp. 72-74). The process of creating such images is described as follows: "A craftsman of Sikachi-Alyan petroglyphs in some cases intentionally selected for his work the ridges of the basalt boulders with two neighboring facets of a stone, placed with an angle, so that a drawing could be placed on these two surfaces. Due to this arrangement, it acquired volume and looked as a 3-D object, not as an image on the surface" (Okladnikov, 1971: p. 77). There are ten suchlike images-faces from Sikachi-Alyan in the tables of A.P. Okladnikov.

Such kind of petroglyphs are also noticed in Sheremetievo and in Sikachi-Alian as well as in the lost site-the cave Medvejii Scheki (Figure 4).

A. P. Okladnikov paid attention to the extensional (three-dimensional) technique of Sikachi-Alyan images; however, he did not include them in the separate group.

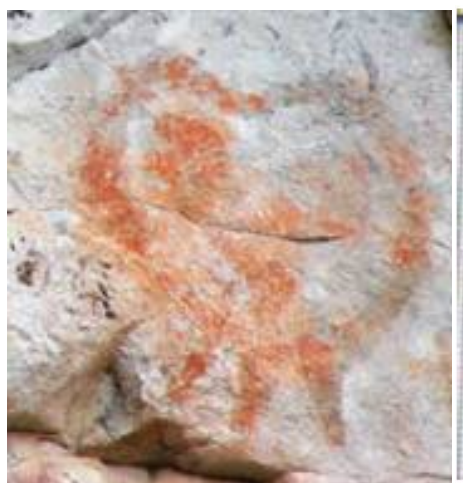

(a)

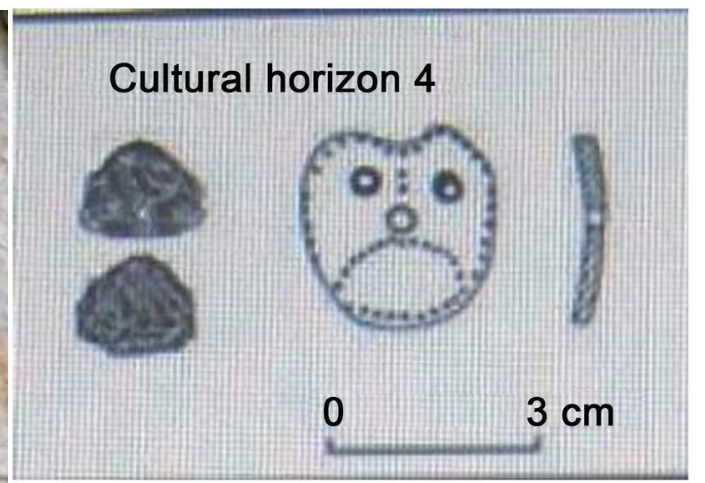

(b)

Figure 3. (a) Vishera rock painting "Pisanyi kamen" (Ural, Russia, Eurasia) (https://lenkovsky.livejournal.com/28477.html\#/28477.html); (b) Artifacts from the cave settlement Yong-ok (Li, 2003: p. 75).

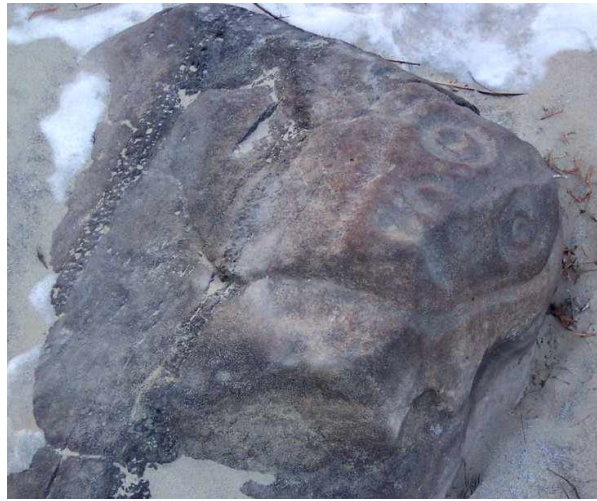

(a)

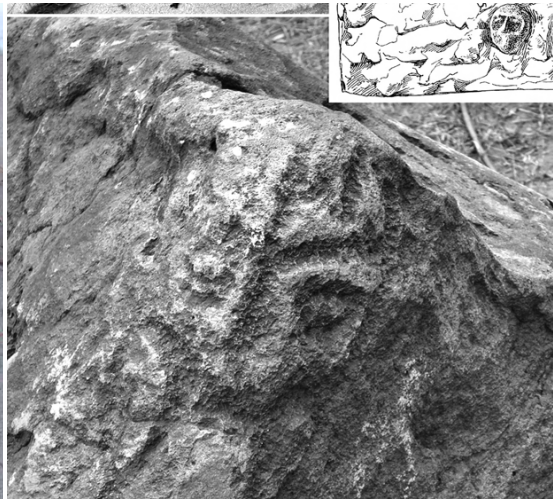

(b)

Figure 4. (a) Relief face on the edges of the facets. Sikachi-Alian (Devlet \& Devlet, 2011: p. 181); (b) 3-D anthropomorphic image, Sikachi-Alian (Devlet \& Laskin, 2014: p. 19); both images, despite different stylistics have one and the same principle-they are done on the corners of the stones. 
This kind of 3-D images (heart-like anthropomorphic faces) were found in Europe (in the cave Altamira, Spain) and in the so called "Park of stones" (Tianya Haijiao) in China, on the island Hainan. In this park, on the way to a spring coming from the cliff, an anthropomorphic corner image was spotted (Mironova, 2017) (Figure 5(b)). If we compare this image with the image of the stone God from the Altamira cave (Dubrovskii \& Grachev, 2011), which was already described in our previous study, we will find out their close similarity (Figure 5(a) \& Figure 5(b)).

The stylistics of images is the same-the horizontal cut for the "mouth", the same way the eyes are done (the left eye of the stone image from China is seen due to the shadowed contours just like the contoured eyes on the stone image from Altamira) and the same way the nose is presented-with the help of stone ridge (where the two surfaces of this boulder are meeting). The only peculiarity that could be found-is more elaborately processed nostrils on the cliff from the stone park Tianya Haijiao, China. Here we see that the nose is formed with two vertical cuts, coming down under widening angle from top (Figure 5(b)).

It is impossible to date precisely the image on the cliff from Tianya Haijiao, China, as soon as there are no any modern instruments to define the chronology of lithic artifacts. But following the fact, that these images are almost identical, we could presuppose that the anthropomorphic image from Tianya Haijiao, China has the same history as the image from Altamira (the same religious cult of Great Goddess). The gigantic territory (Eurasia) that was under the influence of this cult can provoke nothing but astonishment and desire to find an answer to the riddle of Great Goddess cult wide spread.

A very close stylistics in depicting anthropomorphic images was recently discovered by us (Mironova, 2017) in the Western Caucasus, on the wall of a dolmen near Gelendzhik (Figure 6(a)).

We also paid attention to the other stone wall of this megalith-it looks like a

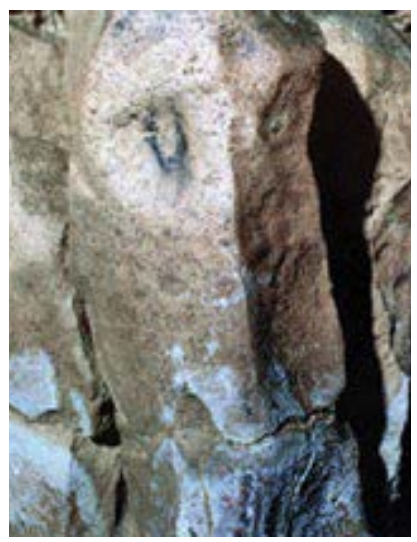

(a)

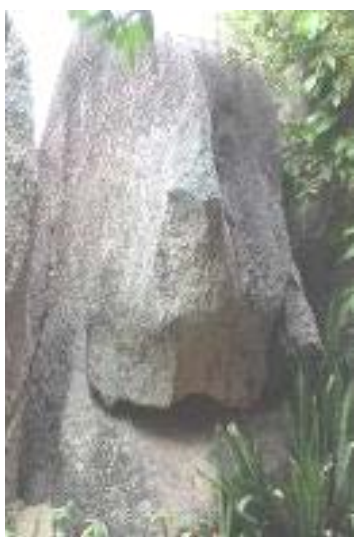

(b)

Figure 5. (a) One of the images which was discovered in the fare most halls of the Altamira cave, Spain (Dubrovskii \& Grachev, 2011: p. 26); (b) a cliff with an anthropomorphic corner image in the park "End of the world", Tianya Haijiao, China (Photo by Elena A. Mironova). 


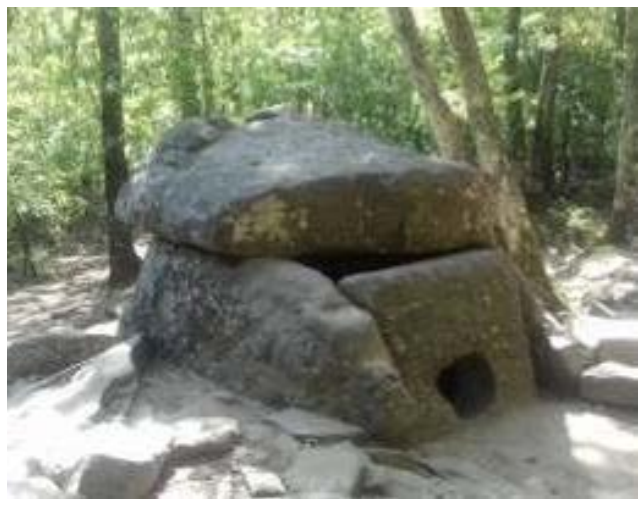

(a)

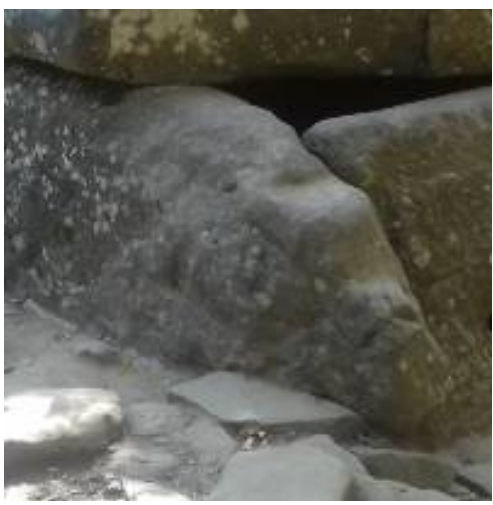

(b)

Figure 6. (a) One of the two side walls of the dolmen on the river Jane (Western Caucasus) with the anthropomorphic image (Photo by Elena.A. Mironova); (b) magnified fragment of the dolmen side wall with the anthropomorphic image (Mironova, 2017).

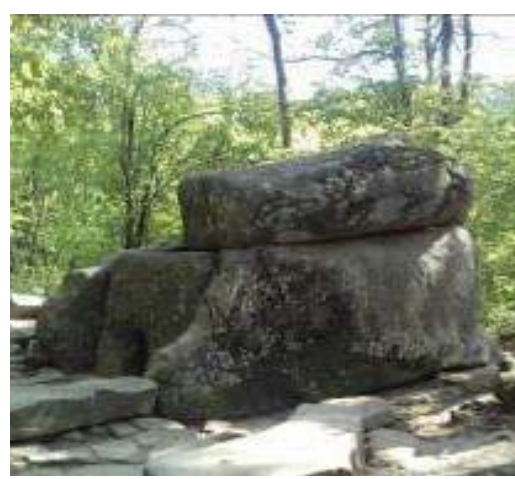

(a)

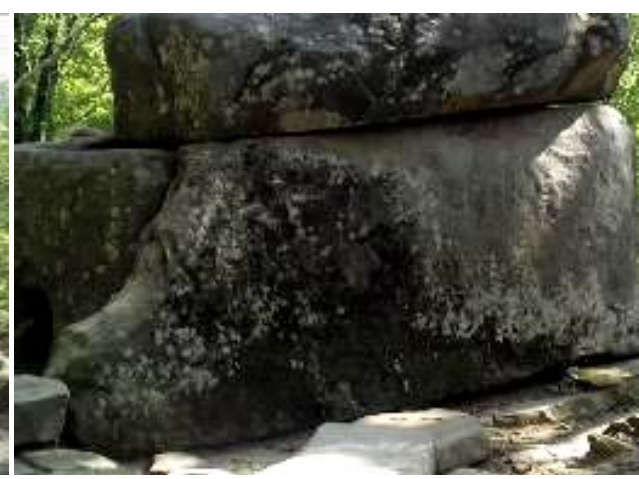

(b)

Figure 7. (a) Dolmen on the river Jane, not far from Gelendzhik; its side wall has a zoomorphic shape (Photo by Elena A. Mironova); (b) Magnified fragment of the dolmen side plate with the zoomorphic image-a bear (Mironova, 2017).

bear (Figure 7(a) \& Figure 7(b)). This wall, which supports the roof of the dolmen on the other side, has a very recognizable features of a bear muzzle: from the angle that is presented on the photo one can see a prolonged nose with two nostrils, a horizontal cut for a mouth (deep incision in the stone below the nose) and folds above-on the place of a supposed eye (the magnified fragment is presented on the Figure $7(\mathrm{~b})$ ).

Thus, in one megalithic construction-in the dolmen on the bank of the river Jane near Gelendzhik (the Western Caucasus, Russia) - we witness a combination of two images: the anthropomorphic image on the two neighboring sides of a first side stone wall and the zoomorphic image (a bear) which is cut on the second side stone wall. According to the ethnographic research in Russia, cult of bear came from the Paleolithic and even now is widely spread on the territories of Ural, Siberia and Altai.

\section{Linguistic Data}

Above mentioned data correlates with the hypothesis by Elena A. Mironova 
(Mironova, 2008) that proto-syllables might well persist in the names of the present-day place-names, titles of the same rituals, holy artifacts, votive objects, as a result of the same or close ethnic groups migrations across the territory of Eurasia.

All this indicates the traces of the same ethnos presence. The ethnos which had the same culture and the same proto-language. Since the first explorers gave the names to the geographical objects on the basis of the words (or parts of the words-protosyllables) from their language, the basic traces of this proto-language should be found mostly in hydronyms and oronyms. The outstanding geographical objects, such as rivers, lakes, mountains and mountain ranges preserve their names since ancient times as it was noticed by many linguists.

Some languages disappeared, some modernized, but the names of the lakes, rivers, mountains, some landscapes remained till nowadays.

In this article, we continue our research of sounds combinations found in toponyms of the world. The proto-syllable $-^{*} \mathrm{kam}-$, and its combinations: $-^{*} \mathrm{kham}-$; ${ }^{*}{ }^{*}$ cam-; -* cham-composed with phonemes [k], [a], [m]—is considered here because it attracted our attention due to its presence in numerous modern geographical names without changes or modifications by other component parts. Our study uses a set of methods developed by E. A. Mironova:

1) Documentation of similar toponyms with the syllables that were previously researched by comparative linguistics;

2) Fixation of such syllables in the words with similar semantics in the languages belonging to the different language families;

3) Verification of studied proto-syllable collocations with each other in the geographical names;

4) Involvement of archeological, anthropological, paleographical, DNA-genealogy data, cultural and religious heritage researches.

According to these steps, we can testify that the syllable - ${ }^{*}$ kam- (with its phonetic variants) was identified in the following toponyms-Cham (Germany), Kam (Nigeria), and also with some changes: Kama (Congo), Kama (Russia, Komi-Permiak region), Kama (Russia, Novosibirskaya Oblast), Kama (Russia, Udmurt Republic), the river Komun-Papua New Guinea.

The very famous toponym is the Kama-the Caspian Sea basin river, the biggest tributary of the Volga River. The Kama passes through the Udmurt Republic, Kirovskii Region, Perm Region, Republic of Bashkortostan and the Republic of Tatarstan. The name Kama is of the Udmurt language: kam-stands for "river", "stream", the same meaning as in Tatar-"chumlan". The name of the river till nowadays was believed to be of Finno-Ugric origin.

It is noteworthy that Udmurt meaning of the river Kam is very much in tune with the word "kem"-which means "river" on the language of ancient Indo-Europeans.

In addition to the above mentioned toponyms, the syllable - ${ }^{*} \mathrm{kam}-$ is found in many identical toponyms- "Kamenka", throughout the whole territory of Rus- 
sia. Thus there are cities and localities with the same name "Kamenka" in: Arkhangelsk, Volgograd, Penza, Smolensk, Tambov, Cherkassk regions, Nenets autonomous area, Primorsky region and also in Kazakhstan. There are five toponyms "Kamennoe" in Kazakhstan, Russia and Ukraine, and also various derivatives such as Kamen, Kamensk, Kamenniki, Kamen-na-Obi, Ust-Kamenogorsk and many others (Illustririvannyi atlas mira, 2006). In this regard, it is worth mentioning that this proto-syllable is present in the names of highlands in the north-west of Russia: Kanin Kamen, Kosminskiy Kamen, Chetlasskiy Kamen.

Following the above mentioned enumeration we can state that absolutely different geographical objects-rivers and mountains-were called with the help of such sound combination [kam]. Therefore there is a need to identify something common that unified these different objects in the conscience of ancient people and allowed them to call the mountains and water/rivers identically.

As a result of our study we revealed that geographical objects are not the only ones that have the same proto-syllable in their names. This syllable is also found in the name Chams or Cham-the people, who live in the Southern Vietnam. Cham people arrived in peninsular Southeast Asia some 4000 years ago, patterns and chronology of migration remain debated. However, in Soviet Encyclopedia we found an article describing the name by which the natives identify themselves as Tyam or Kiam, more likely people could be called as Kiams or Kams. For centuries, this people propounded Hinduism, contracted temples dedicated to Valmiki as well as to Fertility Goddess Ponagar, whose temple till nowadays remained on the mountain of the city Nha Trang. Probably this people are the descendants of Indo-Europeans after their long migration to this region.

Camuni or Camunni (Italy) is another ancient tribe of obscured origin. The Valley of Camunni or Val Camonica is the region famous for the largest rock art in Europe. One theory is that Camunni was a part of the Rhaetian peopleidentified as Etruscans. Gravestones rubbings and rock carvings based on North Etruscan language constitute evidence of this theory.

The next step in studying the cause of proto-syllable sound combination -* kam- wide spread is an examination of its semantics by means of comparison of lexemes including this syllable in the different language families.

As it was mentioned above, in Udmurt language the word "kam" means "river", which is in tune with the Indo-Europeans "kem"- "river" as well. What is remarkable is that in Sanskrit the proto-syllable - ${ }^{*}$ kam- can be found in the words related to water (as element) directly or to some objects connected with water. In the Sanscrit-Russian vocabulary we found lexemes as follows:

कमठ kamatha m.--turtle (Kochergina, 1987: p. 149);

कमणडलु kamandalu m.-pitcher or hermit's vessel for water (Kochergina, 1987: p. 149).

The deities associated with ascetism (Shiva, Brahma) or with water (Waruna, Ganges, Sarasvati), often pictured carrying kamandalu in their hands (Darian, 2001: p. 60). Such images commonly found in iconography. The deities Agni and 
Brihaspati sometimes are portrayed with this vessel-kamandalu. The Devi Mahatmyam (religious book) describes the goddess Brahmani who laid the demons down by means of pouring the water on them from kamandalu.

कमल kamala m., n.-lotus flower. Lotus flower, as we know, is an amphibious plant, and it is another equally important symbol in Buddhism connected with femininity, purity and fertility.

In Sanskrit a letter क (ka) has the following meanings: 1) nom. pr. about many gods; 2) sun; 3) soul; 4) body; 5) time; 2. n. 1) happiness; 2) water; 3) head.

Now when we know that one of the meanings of this word is water, we can figure out semantics of each syllable in the words mentioned above.

So, if we take away the letter क (ka) from the word-कमणडलु "kamandalu", we will get the word मणडलु_ "mandala", which means "round-shaped", "the sun's disc", "ball”, "circle", "ring”. It can be assumed that the word "kamandalu" literally means "round-shaped water", since the water takes the form of a vessel. Now we take a look at another lexeme-कमल "kamala". Removing initial letter क (ka) we are getting word मल-“ mala" which means "dirt", "filth". Lotuses grow in shallow and murky waters. Furthermore, in Hinduism the Lotus flower is a representative of purity and of the process how a person can become awakened to the spiritual reality-grew in the mud however the flower never gets dirty.

The lexemes with pto-syllable - ${ }^{\star}$ kam- were fixed in the Dahl's Dictionary of the Russian language. Those lexemes denote water-related ancient artifacts, namely: "kamia" - sort of a boat, ferry made of solid wood, or made of two hollowed out logs. The word "kamia" is used in Pskov region (Dal, 2008-2017).

Word "kam" in Altai region means-"shaman" (Dal, 2008-2017). Kamlanie (magic action) is the main rite by means of which shaman communicates with the spirits. One of the places where kamlanie enacts is located in the meadow close to the confluence of the Katun and the Sema rivers. At the moment, near this place there is the Gorno-Altaiskiy Botanical Garden, which is close to Kamlak village (Shebalinskiy region). The village name derives from the word "kamlanie". Here we can state the presence of the protosyllable - ${ }^{*} \mathrm{kam}-$, which constitutes the sacral word "kamlanie" and the name of the village-Kamlak (Shauchulene, 2014).

It is interesting to note, that proto-syllable $-{ }^{*} \mathrm{kam}-$ could be found in Japanese lexemes related to religion. For example, “kami” (神) (Japanese-Russian Dictionary) is the Japanese word for "god", "deity" or "spirit". Probably the Japanese word was borrowed from the extremely distant ancestor, because Japanese does not normally distinguish grammatical number in nouns (the singular and plural forms of nouns in Japanese are the same), it is sometimes unclear whether "kami" refers to a single or multiple entities. At the same time, we found that in Sanskrit Kama-god of love in Hinduism.

A well-known linguist, Ono Susumu, refers word "kami" to the ancient "kamu", which specifies three main meanings of the word: 1) thunder, scourge; 2) 
wild beast such as a tiger or a wolf; 3) mountains (Nakorchevski, 2003). Kami could inhabit people during rituals for transmitting their will, which is exactly the same what kamas in Altay region do when kama (shaman) is inhabited by spirit for communication.

Further examination of the proto-syllable $-{ }^{*}$ kam- in Japanese language revealed another quite interesting lexeme, 〈も【雲】(kumo)[1-512-2-26]cloud; の cloudy; derivative: 雲を頂いた cloud covered, hidden in the clouds (about peak); 雲をしのぐ, 雲に敢える uplift to the sky; 雲を衝/ツ/くばかりの, 雲 を摩す様な hitting the sky, rises to the sky; ৩心の雲 (Japanese-Russian Dictionary).

Connections of meanings "height"/"mountain" and "water" presented in the proto-syllable ${ }^{*} \mathrm{kam}$ - remained in Japanese language as a reflection of natural cycles observation: mountain is covered with the clouds, from which rain drops onto the ground.

In Russian-Persian dictionary a word "kam" كـ - means "wish", "power", and a word Kamran ران كام means "lucky", "happy" (Rubinchik, 1970).

In Maya culture the archaeologists found ceramics Mamom (2000 - 500 B.C.) in the low layers of Peten, which is of very simple shape. One of the most common types of vessels among this ceramics is the type, called "kum"-the round clay pots which remain almost unchangeable during the whole Maya history (von Hagen, 2013: p. 233).

Furthermore, in accordance with the proto-syllable research methodology, next step is to search toponyms with the combinations of proto-syllable - ${ }^{\star}$ kamwith already studied proto-syllables. Such toponyms exist in the following places: village Malie Kamkali and lake Bolshie Kamkali-ending point of Chu river (Kazakhstan) - these toponyms have combination of proto-syllables - ${ }^{\star} \mathrm{kam}-$ and -*kal-; Another interesting discovery among toponyms is once existed village Kamkali in Dzhankoy Region-Crimea.

Proto-syllables -*kam-, -*ar- were found in the name of the city Cammarata (Sicily). The letter "c" in combination with the letter "a", being pronounced has a phonetic variant [ka]. There are also few toponyms that are very close phonetically, and could be formed with the combination of proto-syllable -*kam- and other proto-syllables: Cam Rahn (Vietnam), Cameroon bay (Cameroon), Kamaran Island (Yemen), village Kamaran (Iran). It means that proto-syllables -*kam-, -*ar-, -*an- are presented in all toponyms mentioned above.

\section{Ethnological Data}

There is a very ancient and very popular holiday which is spread on the vast territories of Russia, from Arkhangelsk to the Far East-the holiday, which is called "Komoeditsy". This holyday is celebrated on 23-d of March (the spring equinox) and is connected with the cult of a bear who wakes up from a hibernation in this period of time. A bear was an ancient hypostasis of God-Volos (Slavic deity, patron of livestock) whom an offering was brought 
(https://dic.academic.ru/dic.nsf/ruwiki/976839).

Bear cult was reflected on the small stone sculptures, examples of which were described earlier. As the researchers state, the cult of bear had a vast area, spreading from Scandinavia and Kolskii peninsula, North-Eastern Europe, all Siberia, the Amur region and taiga zone of North America. The traces of bear cult have been found in Switzerland and even in the antique epoch, in different countries of Asia Minor and in Taurida (Vasiliev, 1948: p. 78).

\section{Conclusion}

Following the analyzed data, it must be noted, that our findings are as follows: 1) proof that the syllable -*kam- is ancestrally inherited proto-syllable, which migrated to distant locations, can be found in toponyms all over the Eurasian continent and Indo-China; 2) these toponyms are directly or indirectly associated with water, highlands, mountains or rocks; 3 ) link of the concepts "water" and "mountain"/"rock" is found in Japanese language, which has the lexemes with the proto-syllable -*kam-: "cloud", "hidden in the clouds (about peak)". According to the ancient people mindset these two culture-specific elements were inextricably linked-the mountain as an object, over which the clouds are gathering. Rain appears from these clouds. That is why both objects were named with the same sound combination, namely, with the proto-syllable -*kam-; 4) proto-syllable $-{ }^{*} \mathrm{kam}$ - was found in lexemes of different language families, but of similar content and meaning. Lexemes with such proto-syllable were the names of gods or were related to the god's worship, rituals connected to invocation or communication with spirits. The key feature of most rituals was water.

As a result, wide spread of proto-syllable - ${ }^{*} \mathrm{kam}$ - in toponyms, and its presence in the lexemes related to the sacral field, as well as the combination of the proto-syllable -*kam- with already studied proto-syllables in toponyms, suggest to refer it to the ancient language spoken by an ethnos-ancestor.

\section{Conflicts of Interest}

The authors declare no conflicts of interest regarding the publication of this paper.

\section{References}

Bocharova, E. N., \& Zotkina, L. V. (2017). Trasological Research of Plumbaginous Subject from the Settlement Kazachka-I. Studies of V (XXI) Russian Archaeological Congress in Barnaul-Belokuriha, 1, 21-25. http://elibrary.asu.ru/xmlui/handle/asu/3896?show=full

Dal, V. I. (2008-2017). The Explanatory Dictionary of the Living Russian Language. http://slovardalja.net/letter.php?charkod=202

Darian, S. G. (2001). The Ganges in Myth and History (p. 60). Delhi.

Derevianko, A. P. (2011). Three Scenarios of the Transition from the Middle to the Upper Paleolithic Age. Second Scenario: The Transition from the Middle to the Upper Paleolithic Age in the Continental Part of Eastern Eurasia. Archaeology, Ethnography and 
Anthropology of Eurasia, 45, 2-27.

Devlet, E. G., \& Devlet, M. A. (2011). Treasures of the Rock Art of the Northern and Central Asia. Moscow: IA RAS, 181.

Devlet, E. G., \& Laskin, A. R. (2014). To the Study of the Amur and the Ussury Petroglyphs. Brief News of the Institute of Archaeology, 232, 8-32.

Dubrovskii, D. K., \& Grachev, V. Yu. (2011). Ural Paintings in the World Rock Art. Yekaterinburg: Grachev and Partners Ltd., 216.

Generalov, A. G. (2001). Late Paleolithic-Early Mesolithic of Kansk-Yenissey Region. Synopsis of Dissertation, 42.

Japanese-Russian Dictionary. http://warodai.ru/lookup/index.php

Klyosov, A. (2012). Ancient History of the Arbins, Bearers of Haplogroup R1b, from Central Asia to Europe, 16,000 to 1500 Years before Present. Advances in Anthropology, 2, 87-105. http://file.scirp.org/pdf/AA20120200005_67411104.pdf https://doi.org/10.4236/aa.2012.22010

Klyosov, A. A. (2011). "Out of Africa” Theory Re-Examined. Proceedings of the Russian Academy of DNA Genealogy, 4, 1908-1907. (In Russian)

Klyosov, A. A., \& Rozhanskii, I. L. (2012). Haplogroup R1a as the Proto-Indo-Europeans and the Legendary Aryans as Witnessed by the DNA of Their Current Descendants. Advances in Anthropology, 2, 1-13. https://doi.org/10.4236/aa.2012.21001

Kochergina, V. A. (1987). Sanskrit-Russian Dictionary. Moscow: Russian Language, 944.

Kovalenko, S. V. (2015). Monuments of Osinoozersky Neolithic Culture of the Left Bank of the Upper and Middle Amur. Russia and China: History and Perspective of Cooperation: Materials of the $Y$-th International Scientific-Practical Conference (pp. 49-57). Blagoveshchensk: Publishing House BGPY.

Li, H. J. (2003). The Transition Period from the Middle to the Upper Paleolitic Age and Tradition of the Instruments on the Flakes on the Korean Peninsula. Archaeology Ethnography and Anthropology of Eurasia, 1, 65-79.

Lozovskii, V. M. (2014). Flint Industry of the Settlement Zamostie 2 Mezolithic Layers. Stone Age from the Atlantic to the Pacific: Zamyatninskii (Vol. 3), 244-292. http://kunstkamera.ru/files/lib/978-5-88431-251-7/978-5-88431-251-7_20.pdf

Mironova, E. (2014). Mountains and Stones in Prehistory of Humanity (Explanation of Wide Spread of Great Goddess Heart-Like Images Worldwide since the Stone Age). Advances in Anthropology, 4, 243-256. https://doi.org/10.4236/aa.2014.44026

Mironova, E. A. (2017). Comparison of the Pebble-Sculpture from the Gelendzhik Bay and the Object from Graphite from the Location Kazachka-I (Krasnoyarsk Territory). Academy of Trinitarism. http://www.trinitas.ru/rus/doc/0211/002a/02111200.htm

Mironova, E. A. (2008). Universalism of Semantics of Protolanguage Syllables. In Pre-Cirillic Slavic Writing and Pre-Christian Slavic Culture (Volume 1, pp. 65-76). Saint-Petersburg: LSU by A.S. Pushkin.

Mironova, E. A. (2013). Similar Ceramic Forms, Coinciding Ornaments and Identical Signs on the Artifacts of the Cultures of the Neolithic, Chalcolithic and Bronze Age in Europe, Asia and North America (Comparison of the Data From: Kukuteni/Tripillia Yangshao Ban-Chiang Anasazis/Mogollion). Proceedings of the Academy of DNA Genealogy, 6, 267-374. http://dna-academy.ru/wp-content/uploads/6_2_2013.pdf

Mironova, E. A., \& Popov, V. V. (2013). Proof of the Unique Religious Cult Spreading in the Neolithic Age on the Territory of Eurasia, Japan and America (Heart-Like Images of the Great Goddess). Proceedings of the Academy of DNA Genealogy, 6, 1103-1113. 
http://dna-academy.ru/wp-content/uploads/6_6_2013.pdf

Nakorchevski, A. A. (2003). Japan Shinto (p. 236). Saint-Petersburg: Azbuka-klassika.

Okladnikov, A. P. (1971). Petrolyphs of the Low Amur (p. 329). Leningrad: Nauka.

Ongudai (2014).

http://bezogr.ru/issledovateleskaya-rabota-po-teme-analiz-kuleturi-i-religiozni.html

Rubinchik, Yu. A. (1970). Persian-Russian Dictionary (p. 301). Moscow: Russian Language.

Sergeev, G. M. (1962). Physical and Geographical Zoning of the Kanskaya Forest-Steppe. Izvestiya Krasnoyarskogootdela VGO, 2, Krasnoyarsk.

Shauchulene, E. M. (2014). Analysis of the Culture and Religious Believes of the Altai Republic Peoples and Influences of These Believes on Literature and Culture.

Stolyar, A. D. (1985). Origin of Painting Art (p. 298). Moscow: Iskusstvo.

https://lenkovsky.livejournal.com/28477.html\#/28477.html

Vasiliev, B. A. (1948). Bear Holiday. Soviet Ethnography, 4, 78-104.

von Hagen, V. (2013). The Ancient Sun-Kingdoms of the Americans. Aztec, Maya, the Incas. Moscow: JSC Centerpoligraph, 539.

Yong, Ed. (2013). Americas' Natives Have European Roots. Nature.

http://www.nature.com/news/americas-natives-have-european-roots-1.14213 